\title{
On the connection between spatial development and sustainable landscape in the Northern Great Plain region ${ }^{1}$
}

\author{
Gábor Kerékgyártó \\ University of Debrecen Centre for Agricultural and Applied Economic Sciences, Faculty of Agricultural and Food Sciences and \\ Environmental Management, Kerpely Kálmán Doctoral School of Crop Production, Horticulture and Regional Sciences, Debrecen, \\ kerekgyarto@agr.unideb.hu
}

Keywords: spatial development, potencial of landscape, sustainable landscape, the northen great plain region

\section{SUMMARY}

This paper tries to find connection between sustainable landscape and spatial development policy of the Northern Great Plain region on the basis of specific examples explained in scientific literature. Searching for the common roots of spatial development and sustainability the paper explains two interpretations of sustainability from the view point of landscape, than the most significant element of current landscape change - the polarization of landscapes - will be introduced. This trend in landscape change basically determines the direction of spatial development. This paper analyses the Northern Great Plain region from two different approaches. In the first grouping the region is exposed from the view point of spatial development. In the second partitioning the area is divided into subject matters based on the principles of sustainability and polarization of landscape. This research - analyzing development plans and strategies - considers the current situation within the subject matters.

\section{THE AIM OF THE STUDY}

The study is intended to draw people's attention to the connections between spatial development policy and sustainable landscape. In addition to defining the sustainability of landscapes it analyses the region's spatial development policy. Emphasizing the most significant deformities it outlines the possible sustainable development directions. The study makes an effort to connect the specialties of landscapes and the ways of spatial development by analysing the sustainability. In this process the region will be divided into well-defined areas, where principles of sustainability can be enforced. The theme groups touch on the urban areas, the rural agrarian ranges, the underdeveloped small village and homestead areas and the extensive or intensive land uses which have recreational potential.

\section{SPATIAL DEVELOPMENT AND SUSTAINABILITY}

The Northern Great Plain region, as one of the most underdeveloped regions of Hungary, contends with many economic and social problems which can be solved by conscious development practices. Currently, spatial development practices are not able to realize the interventions on the corresponding regional level. The European Union inspires regional thinking by the distribution of resources but the domestic developing methods by-pass the regional level and work with smaller, administrative regions instead of functional regions.

The spatial development and planning law defines the concept of the spatial development. The object of the spatial development is the monitoring and evaluating the economic, social and environmental territorial processes in the whole country or only particular regions of the country and assigning the necessary methodical ways of development. Short-, middle- and long-term comprehensive goals, conceptions and plans have to be defined, harmonized and implemented in the frame of development programs and they have to be proven in other sectoral decisions (1996. évi XXI. Törvény). The spatial development is intent on developing the optimal economic, settlement and spatial structure together with mending the living conditions while it guarantees the principle of sustainable development.

In 1987 the Brundtland Report, also known as Our Common Future provided a key statement on sustainable development, defining it as: "development that meets the needs of the present without compromising the ability of future generations to meet their own needs" (Net.1.). In the course of spatial development we have to consider the limits of natural and environmental loadability besides satisfying the economical and social needs.

The main trends of the regional spatial development are defined by the National Spatial Development Conception (1998), the National Development Plan (2004-2006) and the New Hungary Development Plan (2007-2013). The territorial relevance of the concept is defined by the National Spatial Settlement Plan (2003. évi XXVI. törvény). We have to consider other sectoral and European Union's aims in addition to the general development policies. Orienting to the previous concepts and plans the development policies of the Northern Great Plain region was defined in the strategic program 2007-2013 (Northern Great Plain Regional Strategic Program 2007-2013, NGPRSP). The North Great Plain Operational Program includes the operational tasks of the NGPRSP and they serve together the development of the region acting on the aims of the New Hungary Development Plan and the National Strategic Reference Framework.

\footnotetext{
${ }^{1}$ This document is the rewritten, shortened, English version of the paper prepared by Kerékgyártó (2010) for the conference: "Scientists of the future - Future of rural areas" organised in Debrecen, $3^{\text {rd }}$ November, 2010
} 
The comprehensive aim in the regional strategic program features a vision which is strongly environmental conscious, strive for sustainability and at the same time it enhances the competitiveness of the region. It is also supported by the specific targets of the program. The "Eco-region" and the "Agrarian-region" specific targets affect the most underprivileged, rural, peripheral, agrarian areas. In these relatively large areas the environmental conscious implementation of the developments is essentially important. The developments of the "Dynamicregion" and the "Healthy-region" should escalate almost every territorial unit of the region. Areas, which are currently out of the economic circulation of the region, can be revived by the development of tourism.

In addition to the specific aims of the region horizontal principles are appeared, which have to prevail in the course of the realization of the developments. The principles of sustainability, regionalism and validation of the regional approach have to be emphasized, which are essentials from the aspect of the sustainable spatial development. Sustainability is a horizontal principle in terms of environmental protection. It defines that those developments are regarded as sustainable which consider natural and social resources. Sustainability pervades all specific targets of the strategy, the objectives which increase the competitiveness of the economy, revive agrarian areas and support the development of tourism (Észak-alföldi régió Stratégiai Programja 2007-2013).

The sustainable development is based on the validation of the regionalism and the regional approach. Its important elements are the support of integrated developments and bottom-up initiatives. This concept is appeared as one horizontal aim of the operative program. However behind those types of bottom-up programs you cannot find sufficient professional background and financial resources. Implementation of sustainability joins to Local Agenda 21 programs at local and sub-regional level.

The main ideas of this program was created as part of the Agenda 21 program, which were defined in the United Nations Conference on Environment and Development (UNCED) held on June of 1992, in Rio de Janeiro. The aim of the LA-21 is to realize the principles of sustainability with the active participation of local governments and resident population. During an LA-21 program plans are born and realized, which emphasize the natural capital against the economic capital. The LA-21 is a complex program, which plans the future oriented shaping of built environment, infrastructural system, energy supply, transportation, waste treatment, agriculture etc. in line with the development of the natural environment (Net 2.).

Spatial development programs usually stop at the border of the administrative territorial units while current landscape changes cannot be connected to these borders, but affect functionally consistent areas and regions. As a result of this it is not enough to speak about sustainable settlements, but we have to analyze sustainable landscape too. Antrop, in his concept of sustainable landscape - which is itself a contradicting term - explains sustainability two ways. First, sustainability does not refer to particular landscapes. "The idea can refer to the conservation of certain landscape types or values and implicitly the continuation of practices that maintain and organize these landscapes. Second, the idea might refer to sustainability as a main principle for future landscaping. In this case, the concept refers to the potential landscapes have to enhance sustainability, in particular in rural countryside planning and management" (Antrop, 2006). During the analyses of landscapes we have to ask the question how should be sustainable a complex territorial unit which is changing continuously. According to my idea we can consider a landscape sustainable when changes in the landscape proceed harmoniously.

One of the main trends of actual landscape change is the polarization between more intensive and more extensive use of land. "There is a continuing concentration of people and activities in rather small, highly intensive and densely crowded areas". At the same time vast areas of land become disaffected or even abandoned, where the extensive use of land dominates (Antrop, 2006). The spatial development policies have to be concentrated two target area. One of them is dealing with the areas used intensively. These are urban regions, transport infrastructural networks and the surrounded areas, intensively cultivated agricultural places and touristic, recreational territory threatened by excessive use. The other target areas are located in extensive, abandoned, depopulated, rural lands far from centers, difficult to approach them. Developments are interventions to the current state of landscapes, so they can lead landscape changes. The enhancement of the region's landscapes potential must be an important element of the regional spatial development while fulfils the requirements of biosphere. So landscape development programs may represent correctly the requirements of sustainability because they can respond to economic, social and environmental problems at the most sufficient level.

\section{DEVELOPMENT MATTERS AND AREAS REFLECTING LANDSCAPE APPROACH}

Considering landscape capability of the Northern Great Plain region it can be divided into six different territorially units, most of which are geographically diverse. However the real differences among these areas, which are important from the point of view of sustainability, are the differences in values of these landscapes and the differences in landscape types influenced by history. All of these landscapes rich in natural capital and have prominent cultural values. It is possible to connect to these areas (Bereg, Bihar, Hajdúság, Jászság, Kunság, Sárrét and Szatmár) special historical and ethnic traditions (Baranyi, 2009). Preservation of natural and cultural 
values in the region requires creating sustainable land use. Spreading of traditional farming, rehabilitation of damaged, degraded natural areas, organizing cultural programs of local initiative and intensifying the landscape identity have to be supported.

At the same time in addition to the previously mentioned priorities sustainability requires economic development as well, namely in addiction to sustainable use of natural and cultural resources we have to make efforts to improve the regional accessibility, decrease the unemployment level and close up the peripheral areas. Now I will review different subject matters focusing to the Northern Great Plain Region, which emphasize the same landscape sustainability problems.

During the last decades urban regions went through a dynamic development. This statement is true in case of the three county centers of the region and the surrounded residential settlement ring. However the settlement system of the region is extremely differentiated. Mainly low-performing small- and middle size towns join to the fast developing three county capitals (Észak-alföldi operatív program, 2007). Although the size of urban areas is only $23 \%$ of the region, $43 \%$ of the population lives here $(K S H, 2009)$. Special emphasize have to be placed on this areas as a result of the high density. In these regions restrictions of the increase in intensive land use and sustainable development have to be emphasized.

The Northern Great Plain Region is one of the most significant agricultural production areas of the country. This sector is essential in terms of employment as well as in the size of land use. From sustainability point of view it is worth to deal with agrarian areas because of dichotomy of landscape change. Agricultural areas can be intensive or extensive. In case of intensive land use the biodiversity of the area is fairly small, the landscape is unrelieved as a result of large-scale farming, productivity of the soil is continuously decreasing and chemicals and fertilizers pollute the environment. In case of extensive land use agricultural cultivation is sustainable, but as a result of the inefficient support system and the business environment it is less profitable. In the worst cases these rural areas become depopulated and segregated.

I have to separate from the above-mentioned agricultural areas the small village and homestead regions. These areas are mainly rural areas dealing with agricultural cultivation, but they are significantly richer in natural and cultural values than the previously mentioned agrarian territories. The size of these homestead and small village areas is more than $28 \%$ of the region $(K S H, 2008)$. We have these types of settlement system in SzatmárBereg, Nyírség, Hajdúság and the south, south-east part of Jász-Nagykun-Szolnok counties. The homestead settlement system and farming form is special in Europe. The density of population in small village areas is low and as a result of the small size of the settlement the land uses are more diverse within a territorial unit. Currently the sources of conflicts in these regions are social segregation, degraded built and natural environment, incomplete infrastructure, hard accessibility and lack of jobs and financial capital.

Areas with high recreational potential are touristic regions and those territories which are prominent in landscape in the plain environment (water surfaces, forest areas). These regions can be classified into the group of intensive land use from sustainability point of view. The region's greatest unexploited natural potential is in Tisza River and its environment rich in water surfaces. In this region special emphases have to be taken to economic development based on existing water surfaces. Water ecosystems are curiosity in European level that is why its rate has to be increased. The spatial development policy of Tisza region is defined by the Further Developed Vásárhelyi Plan Project, which is a highlighted investment of the eastern part of the country because of flood prevention. Hungary's second largest lake, the Tisza Lake can become one of the country's most important touristic destinations as a result of recreational services in addition to its natural value. The intensive tourism also can be a source of danger that is why ecotouristical investments have to be supported. Analyzing woodlands it is conspicuous that the ratio of forests is below the country average (11.2\% against $19.1 \%)$. The fragmentation of woodlands cause serious problems and the ratio of native tree species is low (Észak-alföldi régió Stratégiai Programja, 2008). Tisza Region, Nyírség and the territory of Hajdúsági Landscape Protection District is rich in forests. From European Union funds forest planting has to be supported, especially on bed soil quality agricultural territories.

The Northern Great Plain Region is especially rich in protected areas. The size of protected area with national importance is more than 144.000 hectare, which is $8.1 \%$ of the region's and $1.6 \%$ of the country's territory (Table 1). Two national parks, six landscape protection districts and twenty natural protected areas are connected to the region. The total size of Natura 2000 areas is almost 367.000 hectare. This contains the Sites of Community Importance and the Special Protection Areas too, thus almost $21 \%$ of the region is under some kind of protection (Kerékgyártó, 2010). Hungary's first national park, the Hortobágy, which is the biggest grassland of Central Europe, rise from the region's natural and landscape values. It is part of UNESCO World Heritage. At the same time it has to be mentioned that the original flora survived only on small areas (Észak-alföldi régió Stratégiai Programja, 2008). The treatment of protected areas is one of the basic tasks of sustainable land use. Sustainability fulfils a preserving function in natural protection. It aspires to protect natural capital's significant values and practices which preserves and organizes them (Antrop, 2006). 
The proportion of Hungary's protected areas, 2008

\begin{tabular}{|c|c|c|c|c|c|c|}
\hline \multirow[t]{2}{*}{ Regions } & Area & $\begin{array}{l}\text { The size of } \\
\text { protected areas } \\
\text { which has national } \\
\text { importance }\end{array}$ & National parks & $\begin{array}{l}\text { Landscape } \\
\text { protected areas }\end{array}$ & $\begin{array}{l}\text { Natural } \\
\text { protected areas }\end{array}$ & $\begin{array}{l}\text { National } \\
\text { important } \\
\text { protected areas }\end{array}$ \\
\hline & \multicolumn{2}{|c|}{ (thousand hectares) } & \multicolumn{4}{|c|}{ Ratio of protected areas in the region $(\%)$} \\
\hline Central Hungary & 691,59 & 77,42 & 6,74 & 4,34 & 0,11 & 11,20 \\
\hline Central Transdanubia & 1111,59 & 88,73 & 3,73 & 3,65 & 0,60 & 7,98 \\
\hline Western Transdanubia & 1132,83 & 121,20 & 7,9 & 2,65 & 0,11 & 10,70 \\
\hline Southern Transdanubia & 1416,87 & 80,95 & 3,12 & 2,23 & 0,36 & 5,71 \\
\hline Northern Hungary & 1343,27 & 197,22 & 6,10 & 8,24 & 0,34 & 14,68 \\
\hline Northern Great Plain & 1772,87 & 144,31 & 4,54 & 3,18 & 0,41 & 8,14 \\
\hline Hajdú-Bihar & 621,05 & 86,63 & 9,76 & 3,82 & 0,37 & 13,95 \\
\hline Jász-Nagykun-Szolnok & 558,16 & 29,17 & 3,57 & 1,40 & 0,26 & 5,23 \\
\hline $\begin{array}{l}\text { Szabolcs-Szatmár- } \\
\text { Bereg }\end{array}$ & 593,65 & 28,52 & 0,00 & 4,20 & 0,60 & 4,80 \\
\hline Southern Great Plain & 1833,73 & 127,64 & 5,33 & 1,39 & 0,24 & 6,96 \\
\hline HUNGARY & 9302,74 & 837,47 & 5,19 & 3,49 & 0,32 & 9,00 \\
\hline
\end{tabular}

Source: based on KSH Regional Statistic Yearbook (2009)

\section{CONCLUSIONS}

The purpose of this mainly theoretical study, which is based on the analyses of scientific literature, was to reveal the connections between sustainable landscape and the spatial development ideas of the region. Sustainability and the principles which reflect landscape approaches appear in the vision of the region's spatial development. At the same time, the current frames of spatial development are not appropriate to treat the arising problems. The study reflected the landscape approach of sustainability and drew attention to the polarization of landscapes. In the course of the realization of developments which are not considering landscape capabilities we have to count with further environmental load in intensive land use areas and in case of extensive land use as a result of social and economic problems the depopulation of landscapes will be the main process in the future. During the elaboration of future development programs, we have to intend on decreasing the negative effects of landscape polarization.

\section{REFERENCES}

1996. évi XXI. törvény a területfejlesztésről és a területrendezésről.

2003. évi XXVI. törvény az Országos Területrendezési Tervről.

Antrop, M. (2006): Sustainable landscapes: contradiction, fiction or utopia? Landscape Urban Plan, 75. 1-2, $187-197$.

Baranyi (2009): A regionális identitás új kihívásai az Alföldön. - Helyünk a világban - alföldi válaszok a globalizáció folyamataira. IV. Alföld Kongresszus elöadásai, 2008. november 27-28., Békéscsaba. Szerk.: Belanka Cs., Duray B. Békéscsaba, MTA RKK ATI Békéscsabai Osztály. 2009. 131-135.

Észak-alföldi operatív program 2007-2013 (2007): HU161PO009.

Észak-alföldi régió Stratégiai Programja 2007-2013 (2008).

Kerékgyártó Gábor (2010): Gondolatok a területfejlesztés és a fenntartható táj kapcsolatáról az Észak-alföldi régióban, Agrártudományi Közlemények

- Acta Agraria Debreceniensis, megjelenés alatt

KSH (2008): Területi Statisztikai Évkönyv, 2007. Budapest, Központi Statisztikai Hivatal.

KSH (2009): Területi Statisztikai Évkönyv, 2008. Budapest, Központi Statisztikai Hivatal.

Net1.: www.ace.mmu.ac.uk/eae/sustainability/older/brundtland_report.html-2011. március 10.

Net2.: www.hahc.hu/az egeszseges varosokrol agenda21.php - 2010. augusztus 22. 